\title{
Temporal variability in bioassays of the stomatal ammonia compensation point in relation to plant and soil nitrogen parameters in intensively managed grassland
}

\author{
M. Mattsson ${ }^{1, *}$, B. Herrmann ${ }^{2}$, M. David ${ }^{3}$, B. Loubet ${ }^{3}$, M. Riedo ${ }^{4}$, M. R. Theobald ${ }^{4}$, M. A. Sutton ${ }^{4}$, D. Bruhn ${ }^{1}$, \\ A. Neftel $^{2}$, and J. K. Schjoerring ${ }^{1}$ \\ ${ }^{1}$ Plant and Soil Science Laboratory, University of Copenhagen, Faculty of Life Sciences, Thorvaldsensvej 40, 1871 \\ Frederiksberg C, Copenhagen, Denmark \\ ${ }^{2}$ Agroscope Reckenholz-Tänikon Rsearch Station ART, Reckenholzstrasse 191, 8046 Zürich, Switzerland \\ ${ }^{3}$ Institut National de la Recherche Agronomique (INRA), UMR Environnement et Grandes Cultures, \\ Thiverval-Grignon, France \\ ${ }^{4}$ Natural Environmental Research Council, Centre for Ecology and Hydrology, Edinburgh Research Station, \\ Penicuik EH260QB, Midlothian, Scotland \\ *now at: Section for Economy and Technology, Halmstad University, 30118 Halmstad, Sweden
}

Received: 5 May 2008 - Published in Biogeosciences Discuss.: 1 July 2008

Revised: 18 December 2008 - Accepted: 4 January 2009 - Published: 11 February 2009

\begin{abstract}
The exchange of ammonia between crop canopies and the atmosphere depends on a range of plant parameters and climatic conditions. However, little is known about effects of management factors. We have here investigated the stomatal ammonia compensation point in response to cutting and fertilization of a grass sward dominated by Lolium perenne. Tall grass had a very low $\mathrm{NH}_{3}$ compensation point (around $1 \mathrm{nmol} \mathrm{mol}{ }^{-1}$ ), reflecting the fact that leaf nitrogen (N) concentration was very low. During re-growth after cutting, leaf tissue concentrations of $\mathrm{NO}_{3}^{-}, \mathrm{NH}_{4}^{+}$, soluble $\mathrm{N}$ and total $\mathrm{N}$ increased along with apoplastic $\mathrm{NH}_{4}^{+}$concentrations. In contrast, apoplastic $\mathrm{pH}$ decreased resulting in largely unaltered $\mathrm{NH}_{3}$ compensation points. Nitrogen fertilization one week after cutting caused the apoplastic $\mathrm{NH}_{4}^{+}$ concentration of the newly emerging leaves to increase dramatically. The $\mathrm{NH}_{3}$ compensation point peaked between 15 and $25 \mathrm{nmol} \mathrm{mol}^{-1}$ the day after the fertiliser was applied and thereafter decreased over the following 10 days until reaching the same level as before fertilisation. Ammonium concentrations in leaf apoplast, bulk tissue and litter were positively correlated $(\mathrm{P}=0.001)$ throughout the experimental period. Bulk tissue $\mathrm{NH}_{4}^{+}$concentrations, total plant $\mathrm{N}$ and soil
\end{abstract}

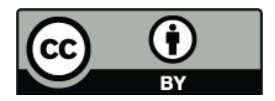

Correspondence to: J. K. Schjoerring (jks@life.ku.dk)
$\mathrm{NH}_{4}^{+}$concentrations also showed a positive correlation. A very high potential for $\mathrm{NH}_{3}$ emission was shown by the plant litter.

\section{Introduction}

Ammonia is emitted from plants when the atmospheric $\mathrm{NH}_{3}$ concentration is lower than the $\mathrm{NH}_{3}$ compensation point, the latter being equal to the $\mathrm{NH}_{3}$ concentration in the substomatal cavity (Farquhar et al., 1980; Husted et al., 1996). In the opposite situation, i.e. when the atmospheric $\mathrm{NH}_{3}$ concentration exceeds the $\mathrm{NH}_{3}$ compensation point, deposition of $\mathrm{NH}_{3}$ occurs. The quantity of $\mathrm{NH}_{3}$ exchanged between crop canopies and the atmosphere may vary between seasons, depending on climatic conditions (Schjoerring and Mattsson, 2001; Sommer et al., 2004). In particular, temperature is known to have a major effect on the $\mathrm{NH}_{3}$ exchange under controlled environmental conditions (Husted and Schjoerring, 1996; Mattsson et al., 1997) as well as in the field (van Hove et al., 2002; Trebs et al., 2006).

The $\mathrm{NH}_{3}$ emission potential of grasslands may vary with species composition (Horvath et al., 2005) because grass species differ in $\mathrm{NH}_{3}$ compensation point (Hanstein et al., 1999; Herrmann et al., 2001; Mattsson and Schjoerring, 2002; Mattsson et al., 2008). In a non-fertilized managed

Published by Copernicus Publications on behalf of the European Geosciences Union. 
grassland in The Netherlands, $\mathrm{NH}_{3}$ emission fluxes were frequent, covering about $50 \%$ of the time in a warm, dry summer period (Wichink Kruit et al., 2007). In contrast, during a wet, cool autumn period, deposition fluxes dominated $(80 \%$ of the time) due to small canopy compensation points caused by low temperatures and a generally wet surface (Wichink Kruit et al., 2007). Nitrogen fertilisation is one of the major management factors of grasslands and $\mathrm{NH}_{3}$ volatilisation can be influenced by the form, timing and dosage of $\mathrm{N}$ fertiliser (Riedo et al., 2002). Measurements of $\mathrm{NH}_{3}$ volatilisation under controlled laboratory conditions have shown that high amounts of $\mathrm{N}$ supplied to the roots increase $\mathrm{NH}_{3}$ emission (Mattsson et al., 1998; Mattson and Schjoerring, 1996) and $\mathrm{NH}_{3}$ compensation points (Mattsson and Schjoerring, 2002). Increasing the $\mathrm{N}$ availability to plant roots leads to elevated steady state levels of different $\mathrm{N}$ pools within the plant tissue. In a field experiment over two years, the $\mathrm{NH}_{3}$ losses from wheat, oilseed rape and barley increased under conditions of high $\mathrm{N}$ concentration in the foliage (Schjoerring and Mattsson, 2001). In a Scottish experiment, a higher $\mathrm{NH}_{3}$ compensation point of the grass was seen after only one of the two cuttings and fertilisations (Loubet et al., 2002). Little is known about the $\mathrm{NH}_{3}$ emission potential of grasslands where repeated cuttings and $\mathrm{N}$ fertilisations are normal management practice. A better understanding of the component parameters influencing the $\mathrm{NH}_{3}$ emission potential is needed in order to model $\mathrm{NH}_{3}$ exchange between grasslands and the atmosphere.

The aim of the present study was to estimate the $\mathrm{NH}_{3}$ emission potential of grassland in relation to common management practice. In order to do this, the temporal variation in the $\mathrm{NH}_{3}$ compensation point and its underlying components of grass leaves and soil were followed at a field site (Sutton et al., 2008), starting with tall grass and spanning subsequent events of cutting, lifting and $\mathrm{N}$-fertilization.

\section{Materials and methods}

The investigation took place as part of the GRAMINAE integrated experiment conducted on a field near Braunschweig from 22 May to 15 June 2000 . The main field was $600 \times 300 \mathrm{~m}$ in size and consisted of a mixed sward dominated by Lolium perenne (around $60 \%$ abundance), Phleum pratense ( $\sim 15 \%$ abundance) and Festuca pratensis $(\sim 12 \%$ abundance; Mattsson et al., 2008). The data presented for leaves of tall grass plants are mean values of these 3 most abundant species, weighted by their relative abundance in the field. The grass was cut on 29 May and lifted for silage on 31 May. An area of $10 \times 10 \mathrm{~m}$ was left uncut for additional sampling of tall grass. Fertilizer $\left(100 \mathrm{~kg} \mathrm{~N} \mathrm{ha}^{-1}\right.$ in calcium ammonium nitrate) was applied on the main field on the 5 June. A $10 \times 10 \mathrm{~m}$ plot was left unfertilized and another plot of the same size received $200 \mathrm{~kg} \mathrm{Nha}^{-1}$ in calcium ammo- nium nitrate. Growth and development of the grass were as described in Sutton et al. (2008).

\subsection{Sampling of plant material}

Throughout the entire experiment, plants were sampled almost every day between 12:00 and 03:00 p.m. (GMT). Cut green leaves were immediately taken to the field laboratory where the apoplastic solution was extracted using a vacuum infiltration technique (Husted and Schjoerring, 1995). Whole leaves were infiltrated in isotonic sorbitol solution $(280 \mathrm{mM})$ at a pressure of 16 bar under vacuum for $5 \mathrm{~s}$. The procedure was repeated 5 times in order to ensure full infiltration. Infiltrated leaves were carefully blotted dry and kept in plastic bags to equilibrate for $15 \mathrm{~min}$ in daylight. Leaf apoplastic solution was extracted by centrifugation at $800 \mathrm{~g}$ for $10 \mathrm{~min}$ at $4^{\circ} \mathrm{C}$. After extraction, $\mathrm{pH}$ of the apoplastic samples was measured with a micro-combination $\mathrm{pH}$ electrode (9810, Orion, Beverly, USA) and samples were frozen at $-18^{\circ} \mathrm{C}$. Leaf samples for bulk tissue $\mathrm{NH}_{4}^{+}$and $\mathrm{NO}_{3}^{-}$analysis were also frozen down at the same time for later extraction. Samples of litter (senescent leaves) and stubble (cut stems) were frozen every day after the grass was cut. For total $\mathrm{N}$ concentration, samples of leaves, litter and stubbles were taken daily and immediately dried in an oven $\left(70^{\circ} \mathrm{C}\right)$ over night. Guttation droplets were collected on the main field and the high fertilized plot between 03:00 and 06:00 a.m. and immediately frozen.

\subsection{Plant analysis}

Ammonium in apoplastic extracts was determined by fluorometry on an HPLC system (Waters Corp. Milford, USA) equipped with a pump, a column oven with a $3.3 \mathrm{~m}$ stainless steel reaction coil, an autosampler cooled to $2^{\circ} \mathrm{C}$ and a scanning fluorescence detector. The reaction between $\mathrm{NH}_{4}^{+}$and $o$-phthaldehyde (OPA) to form an alkylthioisoindole fluorochrome was performed at neutral $\mathrm{pH}$ with 2mercaptoethanol as reducing agent. This fluorochrome was detected at an exitation wavelength of $410 \mathrm{~nm}$ and an emission wavelength of $470 \mathrm{~nm}$ (Husted et al., 2000a).

The plant leaves, litter and stubble were homogenised in $10 \mathrm{mM}$ formic acid in a cooled mortar with a little sand. The homogenate was centrifuged at $25000 \mathrm{~g}\left(2^{\circ} \mathrm{C}\right)$ for $10 \mathrm{~min}$ and the supernatant was transferred to polysulphone centrifugation filters (Size 500- $\mu$ l, mesh $0.45 \mu \mathrm{m}$; Micro VectraSpin, Whatman Ltd., Maidstone, UK) and spun at $5000 \mathrm{~g}\left(2^{\circ} \mathrm{C}\right)$ for $5 \mathrm{~min}$. The filtered solution was used for analysis of $\mathrm{NO}_{3}^{-}$and $\mathrm{NH}_{4}^{+}$concentrations on a flow injection system (Quick Chem instrument, Lachat Istruments INC, Milwaukee, USA). Tissue extracts were also analysed for total soluble $\mathrm{N}$ concentration (so-called substrate $\mathrm{N}$ ) using an ANCASL Elemental Analyser coupled to a 20-20 Tracermass Mass Spectrometer (SerCon Ltd., Crewe, UK). The same equipment was used for analysis of total $\mathrm{N}$ and $\mathrm{C}$ concentrations 
in oven dried plant material ground to a fine powder. For bulk tissue $\mathrm{pH}$ measurements, $0.2 \mathrm{~g}$ sample of leaf material was homogenized in $2 \mathrm{ml}$ of deionized water in a cooled mortar with a little sand. The homogenate was centrifuged at $14000 \mathrm{~g}\left(4^{\circ} \mathrm{C}\right)$ for $10 \mathrm{~min}$ and $\mathrm{pH}$ in the supernatant measured with a microelectrode (Metrohm, Herisau, Switzerland).

\subsection{Soil sampling and analysis}

Soil samples were taken at least every third to fourth day with a soil auger at random positions over the field. Soil cores were separated into two layers $(0-10 \mathrm{~cm}$ and $10-30 \mathrm{~cm})$ and frozen at $-18^{\circ} \mathrm{C}$. A sub-sample was analysed for moisture content by calculating \% weight loss after drying the soil for $24 \mathrm{~h}$ at $108^{\circ} \mathrm{C}$. Another sub-sample $(10 \mathrm{~g})$ was used for $\mathrm{pH}$ measurements after extraction for $1 \mathrm{~h}$ in $25 \mathrm{ml} 0.01 \mathrm{~m} \mathrm{CaCl}_{2}$. Plant available $\mathrm{NH}_{4}^{+}$and $\mathrm{NO}_{3}^{-}$were analysed with flow injection after extraction of $25 \mathrm{~g}$ of soil in $50 \mathrm{ml} 2 \mathrm{M} \mathrm{KCl}$.

\subsection{Calculation of the $\mathrm{NH}_{3}$ compensation point}

The stomatal $\mathrm{NH}_{3}$ compensation point $\left(\chi_{\mathrm{NH}_{3}}\right.$ mol $\mathrm{NH}_{3} \mathrm{~mol}^{-1}$ air) at $25^{\circ} \mathrm{C}$ was calculated by use of Eq. (1) derived from Husted and Schjoerring (1996) taking into account that $K_{d} \ll\left[\mathrm{H}^{+}\right]_{\text {apoplast }}$ within the range of apoplastic $\mathrm{pH}$ values:

${ }^{25} \chi_{\mathrm{NH}_{3}}=K_{\mathrm{H} .25} \times K_{d .25} \times \Gamma=10^{-11.01} \times \Gamma$

$\Gamma$ is the dimensionless ratio between the apoplastic $\mathrm{NH}_{4}^{+}$ and $\mathrm{H}^{+}$concentrations, and $K_{H}$ and $K_{d}$ are thermody-

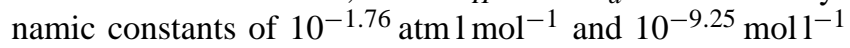
at $25^{\circ} \mathrm{C}$, respectively. Equation (1) literally calculates the pressure of $\mathrm{NH}_{3}$ (unit: atm), which according to Dalton's law of partial pressures is equal to the mol fraction (or volume fraction) at a given atmospheric pressure.

The calculated $\chi_{\mathrm{NH}_{3}}$ at $25^{\circ} \mathrm{C}\left(T_{\text {ref }}\right)$ was adjusted to the actual canopy temperature $T_{c}$ by the following equation derived from Husted and Schjoerring (1996):

$\ln \left({ }^{T_{c}} \chi_{\mathrm{NH}_{3}} /{ }^{T_{\mathrm{ref}}} \chi_{\mathrm{NH}_{3}}\right)=\left(\Delta H_{\text {dis }}^{0}+\Delta H_{\mathrm{vap}}^{0}\right) / R \times$

$\left(1 / T_{\text {ref }}-1 / T_{c}\right)=34.868-10395.91 / T_{C}$

${ }^{T_{c}} \chi_{\mathrm{NH} 3}$ is the requested $\mathrm{NH}_{3}$ compensation point at the actual canopy temperature $T_{c}(\mathrm{~K}), \Delta H_{\mathrm{dis}}^{0}$ the enthalpy of $\mathrm{NH}_{4}^{+}$dissociation $\left(52.21 \mathrm{~kJ} \mathrm{~mol}^{-1}\right), \Delta H_{\text {vap }}^{0}$ the enthalpy of vaporization $\left(34.18 \mathrm{~kJ} \mathrm{~mol}^{-1}\right)$, and $R$ the gas constant $\left(0.00831 \mathrm{~kJ} \mathrm{~K}^{-1} \mathrm{~mol}^{-1}\right)$.

\section{Results}

\subsection{Apoplastic parameters}

The apoplastic $\mathrm{NH}_{4}^{+}$concentration was below $50 \mu \mathrm{M}$ in the tall grass both before and after the main field was cut

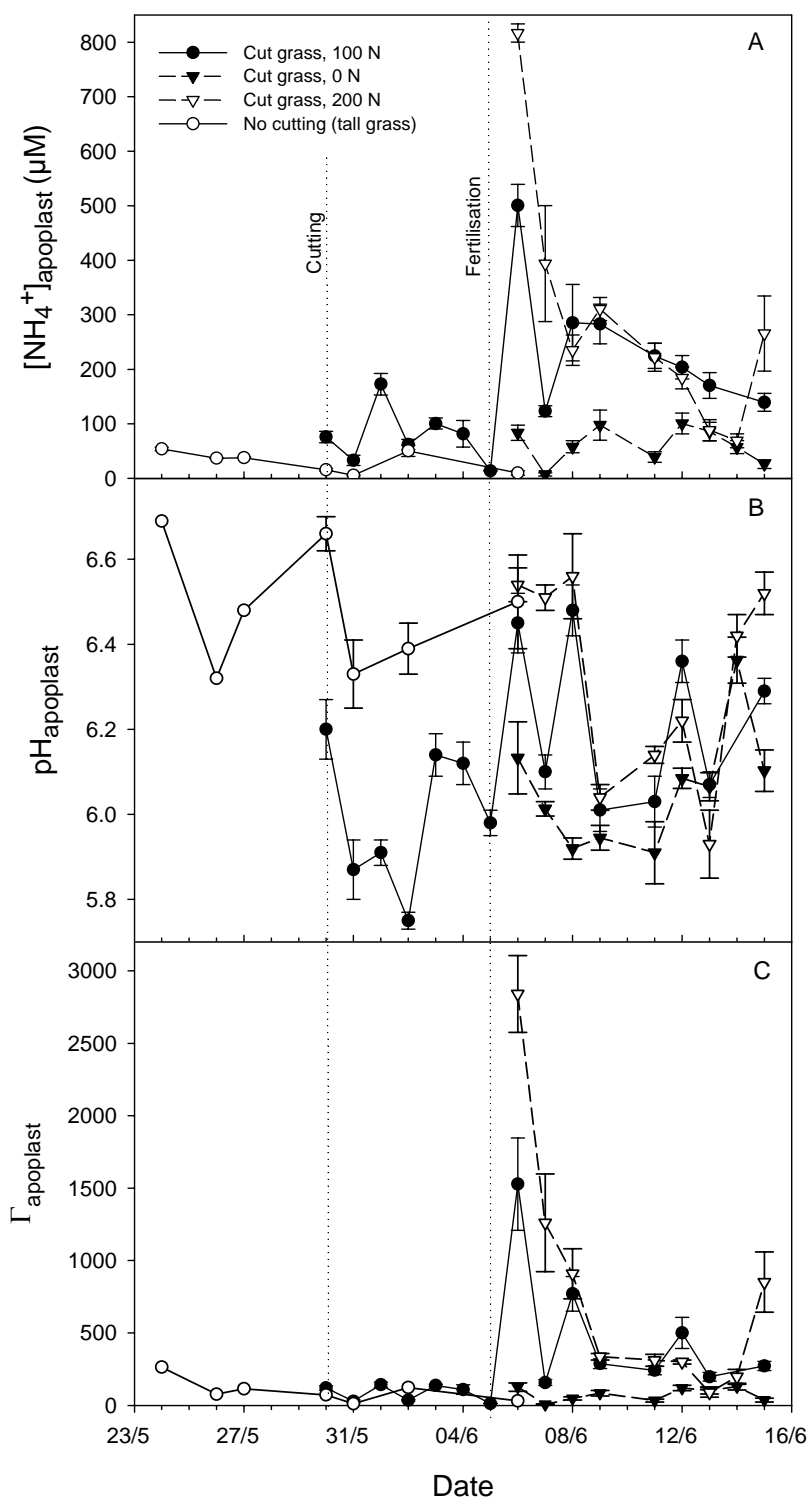

Fig. 1. Temporal variation in A) apoplastic $\left[\mathrm{NH}_{4}^{+}\right]$, B) apoplastic $\mathrm{pH}$, and $\mathrm{C}$ ) the ratio of $\left[\mathrm{NH}_{4}^{+}\right]_{\text {apoplast }}$ to $\left[\mathrm{H}^{+}\right]_{\text {apoplast }}(\Gamma$; dimensionless) in four treatments of a Lolium perenne dominated sward. The grass was cut on 29 May and lifted for silage on 31 May. An area of $100 \mathrm{~m}^{2}$ was left uncut for additional sampling of tall grass. Fertilizer ( $100 \mathrm{~kg} \mathrm{Nha}^{-1}$ in calcium ammonium nitrate) was applied on the main field on 5 June. A $100 \mathrm{~m}^{2}$ plot was left unfertilized and another plot of same size was applied $200 \mathrm{~kg} \mathrm{~N} \mathrm{ha}^{-1}$ in calcium ammonium nitrate. Vertical dotted lines indicate times of cutting and fertilisation, respectively. Values are means of three replicates \pm S.E.

(Fig. 1a). New grass leaves emerging after cutting showed slightly elevated apoplastic $\mathrm{NH}_{4}^{+}$concentrations compared to leaves of the tall grass (Fig. 1a). Following application of $100 \mathrm{~kg} \mathrm{Nha}^{-1}$ to the main field 6 days after cutting of the grass, apoplastic $\mathrm{NH}_{4}^{+}$concentrations rapidly 
Table 1. Tissue extracts of green leaves, stems and senescent leaves (litter) of the main field analysed for $\mathrm{pH}, \mathrm{NH}_{4}^{+}$concentration and the ratio $\Gamma$ between $\left[\mathrm{NH}_{4}^{+}\right]$and $\left[\mathrm{H}^{+}\right]$. Means of 3 replicates $\pm \mathrm{SE}$.

\begin{tabular}{llll}
\hline & $\mathrm{pH}$ & {$\left[\mathrm{NH}_{4}^{+}\right], \mathrm{mM}$} & $\Gamma$ \\
\hline Green leaves & $6.33 \pm 0.02$ & $1.79 \pm 0.01$ & $3827 \pm 171$ \\
Stems & $6.37 \pm 0.04$ & $1.15 \pm 0.14$ & $2696 \pm 282$ \\
$\begin{array}{l}\text { Senescent } \\
\text { leaves }\end{array}$ & $7.03 \pm 0.05$ & $16.2 \pm 1.2$ & $173586 \pm 12917$ \\
\hline
\end{tabular}

peaked at around $500 \mu \mathrm{M}$, but thereafter decreased over the next 10 days until reaching almost the same level as before fertilisation (Fig. 1a). Plants on a plot receiving $200 \mathrm{~kg} \mathrm{~N} \mathrm{ha}^{-1}$ attained a maximum apoplastic $\mathrm{NH}_{4}^{+}$concentration around $800 \mu \mathrm{M}$ (Fig. 1a). When no nitrogen was applied $\left(0 \mathrm{~N}\right.$ plot) apoplastic $\mathrm{NH}_{4}^{+}$concentrations remained below $100 \mu \mathrm{M}$ throughout the experimental period.

Apoplastic $\mathrm{pH}$ was higher in the tall grass compared to the cut grass (Fig. 1b). Fertilisation caused a transient increase in apoplastic $\mathrm{pH}$ without showing any difference between plants receiving 100 or $200 \mathrm{~kg} \mathrm{Nha}^{-1}$ (Fig. 1b). The ratio between apoplastic $\mathrm{NH}_{4}^{+}$and $\mathrm{H}^{+}$concentrations $\left(\Gamma_{\text {apoplast }}\right)$ ranged from 10 to 150 before fertilisation (Fig. 1c). The slight increase in apoplastic $\mathrm{NH}_{4}^{+}$following cutting was counteracted by decreasing $\mathrm{pH}$ (Fig. 1b). Accordingly, $\Gamma_{\text {apoplast }}$ hardly changed between cutting and fertilisation (Fig. 1c). During the first 2 days after fertilisation, $\Gamma_{\text {apoplast }}$ increased to above 1000, but thereafter started to decrease in parallel with the $\mathrm{NH}_{4}^{+}$concentration (Fig. 1c). In the $0 \mathrm{~N}$ plot, $\Gamma_{\text {apoplast }}$ remained below 150 throughout the experiment.

The calculated stomatal $\mathrm{NH}_{3}$ compensation point, $\chi \mathrm{NH}_{3}$, corrected for temperature differences between different days (Eq. 2), was 1-2 $\mathrm{nmol} \mathrm{mol}^{-1}$ before cutting (data not shown). This level was maintained for unfertilised grass after cutting. After $\mathrm{N}$ fertilisation, $\chi_{\mathrm{NH}_{3}}$ peaked at $15-25 \mathrm{nmol} \mathrm{mol}^{-1}$ but decreased to $3-4 \mathrm{nmol} \mathrm{mol}^{-1}$ already 4 days after fertilisation (data not shown).

\subsection{Bulk tissue nitrogen status}

Bulk tissue $\mathrm{NH}_{4}^{+}$concentrations of the tall grass as well as the cut grass prior to fertilisation were lower than $2 \mu \mathrm{mol} \mathrm{g}^{-1}$ fresh weight (Fig. 2a). After fertilisation, bulk tissue $\mathrm{NH}_{4}^{+}$increased rapidly and substantially, peaking around $14 \mu \mathrm{mol} \mathrm{g}^{-1}$ FW with little difference between 100 and $200 \mathrm{~kg} \mathrm{Nha}^{-1}$ treatments (Fig. 2a). Plants not receiving $\mathrm{N}$ fertilizer $\left(0 \mathrm{~N}\right.$ treatment) maintained a bulk tissue $\mathrm{NH}_{4}^{+}$level below $4 \mu \mathrm{mol} \mathrm{g}^{-1} \mathrm{FW}$.

Bulk tissue $\mathrm{NO}_{3}^{-}$concentrations were extremely low in the tall grass (Fig. 2b), while in the new leaves developing after cutting, $\mathrm{NO}_{3}^{-}$increased considerably. Fertilisation caused a dramatic increase (4 to 5 fold) in bulk tissue $\mathrm{NO}_{3}^{-}$and the

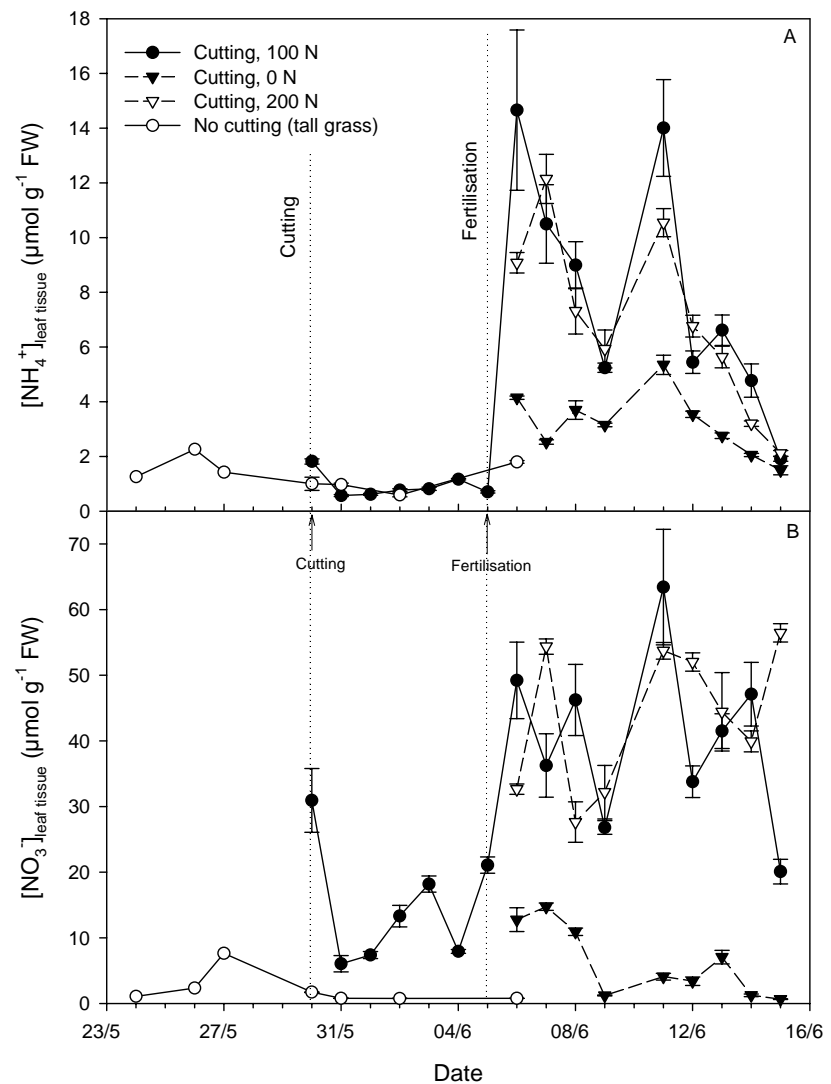

Fig. 2. Temporal variation in (A) leaf $\left[\mathrm{NH}_{4}^{+}\right]$and $(\mathbf{B})$ leaf $\left[\mathrm{NO}_{3}^{-}\right]$on a fresh weight basis in four treatments of a Lolium perenne dominated sward. Details on experimental treatments are given in Fig. 1. Values represent means of three replicates \pm S.E.

high level remained until the end of the experiment (Fig. 2b). In unfertilised grass, $\mathrm{NO}_{3}^{-}$concentrations decreased towards the end of the experiment to values similar to those of the tall grass.

Total $\mathrm{N}$ concentration in the tall grass leaves decreased from $3 \%$ (dry weight basis) before cutting to about $2 \% 9$ days later (Fig. 3b). The remaining part of the cut stems (stubble) also had a total $\mathrm{N}$ concentration of ca. $2 \%$ throughout the rest of the experimental period. In the newly produced leaves of the $100 \mathrm{~N}$ treatment (main field), the total $\mathrm{N}$ concentration increased from around 3\% just after cutting to around 5\% at the end of the experiment (Fig. 3b). The final foliar $\mathrm{N}$ concentration in the 0 and $200 \mathrm{~N}$ treatments were $3.5 \%$ and 5.5 $\%$, respectively (data not shown).

Tissue extracts were also analysed for total soluble $\mathrm{N}$ concentration which can be interpreted as a dynamic $\mathrm{N}$ pool available for plant growth. This so-called "substrate N" was very high in leaves remaining or developing after cutting (Fig. 3a). Following fertilisation, plants in the 100 and $200 \mathrm{~N}$ treatments had significantly higher substrate $\mathrm{N}$ than unfertilised grass $(0 \mathrm{~N}$ treatment). Substrate $\mathrm{N}$ constituted between 10 and $40 \%$ of total leaf $\mathrm{N}$. 
Table 2. Correlation coefficient table for all the different parameters measured and calculated in grass plants and soil from the $100 \mathrm{~N}$ treatment (main field). $r^{2}$ values with level of significance $(*=0.05 ; * *=0.01, * * *=0.001) \cdot \chi \mathrm{NH}_{3}$ is the stomatal compensation point of green leaves.

\begin{tabular}{|c|c|c|c|c|c|c|c|c|c|}
\hline & {$\left[\mathrm{NH}_{4}^{+}\right]_{\text {apo }}$} & $\mathrm{pH}_{\mathrm{apo}}$ & {$\left[\mathrm{NH}_{4}^{+}\right]_{\text {tissue }}$} & $\chi \mathrm{NH}_{3}$ & {$\left[\mathrm{NH}_{4}^{+}\right]_{\text {litter }}$} & {$\left[\mathrm{NH}_{4}^{+}\right]_{\text {guttation }}$} & SubstN & TotN & {$\left[\mathrm{NH}_{4}^{+}\right]_{\text {soil }}$} \\
\hline$\left[\mathrm{NH}_{4}^{+}\right]_{\mathrm{apo}}$ & 0.08 & - & $0.60 * * *$ & $0.84 * * *$ & $0.50 * * *$ & 0.22 & $0.48 * * *$ & 0.27 & 0.23 \\
\hline $\mathrm{pH}_{\text {apo }}$ & 0.08 & - & 0.02 & 0.21 & 0.07 & 0.02 & 0.16 & 0.15 & 0.004 \\
\hline$\left[\mathrm{NH}_{4}^{+}\right]_{\text {tissue }}$ & $0.60 * * *$ & 0.02 & - & $0.48 * * *$ & $0.73 * * *$ & 0 & $0.35^{* *}$ & $0.42 * *$ & 0.29 \\
\hline$\chi \mathrm{NH}_{3}$ & $0.84 * * *$ & 0.21 & $0.48 * * *$ & - & $0.46^{* * *}$ & 0.01 & $0.25^{*}$ & 0.15 & 0.21 \\
\hline$\left[\mathrm{NH}_{4}^{+}\right]_{\text {litter }}$ & $0.50 * * *$ & 0.07 & $0.73 * * *$ & $0.46^{* * *}$ & - & 0.34 & 0.40 & 0.21 & $0.47 *$ \\
\hline$\left[\mathrm{NH}_{4}^{+}\right]_{\text {guttation }}$ & 0.22 & 0.02 & 0 & 0.01 & 0.34 & - & 0.19 & 0.06 & 0.19 \\
\hline SubstN & $0.48 * * *$ & 0.16 & $0.35^{* *}$ & $0.25 *$ & 0.40 & 0.19 & - & 0.23 & 0.44 \\
\hline TotN & 0.27 & 0.15 & $0.42 * *$ & 0.15 & 0.21 & 0.06 & 0.23 & - & $0.68 *$ \\
\hline$\left[\mathrm{NH}_{4}^{+}\right]_{\text {soil }}$ & 0.23 & 0.004 & 0.29 & 0.21 & $0.47 *$ & 0.19 & 0.44 & $0.68 *$ & - \\
\hline
\end{tabular}

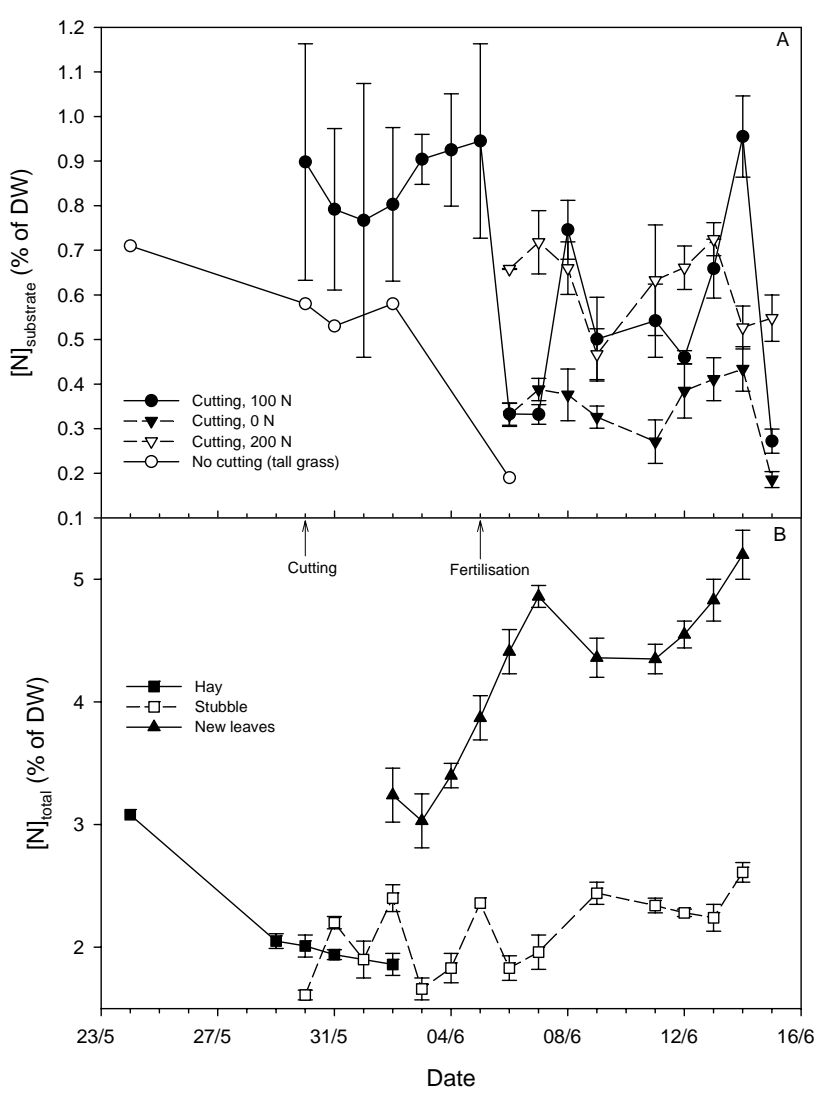

Fig. 3. Temporal variation in (A) concentration of total soluble $\mathrm{N}$ $\left([\mathrm{N}]_{\text {substrate }}\right)$ in leaf tissue, and (B) total $\mathrm{N}$ in new leaves, stubble and hay of a Lolium perenne dominated sward. DW=dry weight. Details on experimental treatments are given in Fig. 1. Arrows indicate times of cutting and fertilisation, respectively. Values represent means of three replicates \pm S.E.

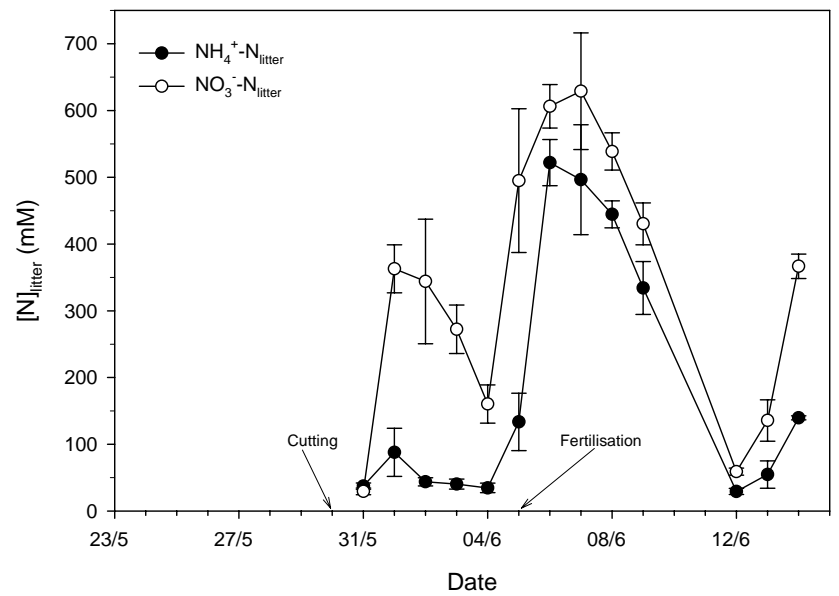

Fig. 4. Temporal variation in litter $\mathrm{NH}_{4}^{+}$and $\mathrm{NO}_{3}^{-}$concentrations in a Lolium perenne dominated sward. Details on experimental treatments are given in Fig. 1. Arrows indicate times of cutting and fertilisation, respectively. Values represent means of three replicates \pm S.E.

The litter component of the grassland consisting of senescent plant leaves either attached to the lower part of the stems or lying on the ground constituted about $20 \%$ of the total above-ground biomass before cutting (data not shown). Prior to cutting, litter concentrations of $\mathrm{NH}_{4}^{+}$and $\mathrm{NO}_{3}^{-}$were below $50 \mathrm{mM}$ (Fig. 3), while 3 days after cutting the $\mathrm{NO}_{3}^{-}$concentration in the litter had increased to about $350 \mathrm{mM}$, while litter $\mathrm{NH}_{4}^{+}$remained below $50 \mathrm{mM}$ (Fig. 4). After fertilization $\left(100 \mathrm{~kg} \mathrm{~N} \mathrm{ha}^{-1}\right)$, litter $\mathrm{NH}_{4}^{+}$increased to around $500 \mathrm{mM}$ but started to decrease again already after a few days (Fig. 4). Nitrate concentrations were slightly higher than $\mathrm{NH}_{4}^{+}$concentrations after fertilisation but followed the same temporal pattern (Fig. 4). 


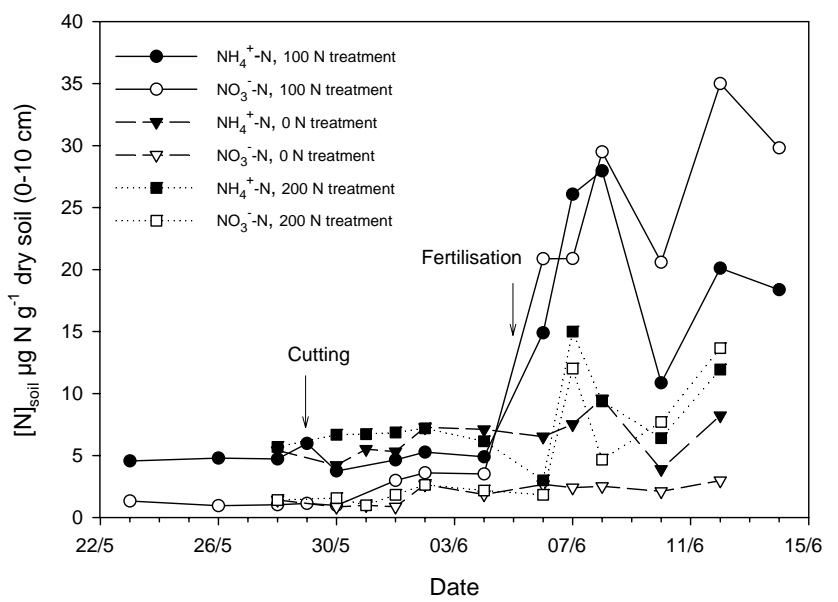

Fig. 5. Temporal variation in $\left[\mathrm{NH}_{4}^{+}\right]$and $\left[\mathrm{NO}_{3}^{-}\right]$of the top layer of soil in three treatments of a Lolium perenne dominated sward. Details on experimental treatments are given in Fig. 1. Arrows indicate times of cutting and fertilisation, respectively.

In parallel to apoplastic extracts, $\mathrm{NH}_{4}^{+}$and $\mathrm{H}^{+}$concentrations in bulk tissue extracts can be used to derive $\Gamma$ values for different plant components of the sward in order to compare their potential $\mathrm{NH}_{3}$ exchange (Table 1). Bulk pH values of green leaves and stems were similar to those in the apoplastic solution ranging between 6.2 and 6.6 (Table 1; Fig. 1b). Due to higher $\mathrm{NH}_{4}^{+}$concentrations in the tissue extracts (Table 1) than in the apoplastic solution (Fig. 1a), the resulting $\Gamma$ value in green leaves was around 40 times higher than $\Gamma_{\text {apoplast }}$ (Fig. 1c). Extracts of plant litter showed both higher $\mathrm{pH}$ and, particularly, $\mathrm{NH}_{4}^{+}$concentrations compared to leaves

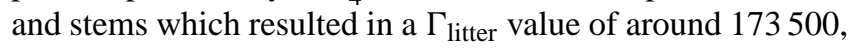
i.e. 45-60 times higher than $\Gamma_{\text {leaf }}$ and $\Gamma_{\text {stem }}$ (Table 1).

\subsection{Soil parameters}

Soil $\mathrm{NH}_{4}^{+}$and $\mathrm{NO}_{3}^{-}$concentrations (Fig. 5) were low before fertilisation with $\mathrm{NH}_{4}^{+}$concentrations being higher than $\mathrm{NO}_{3}^{-}$concentrations in both the top soil fraction $(0-10 \mathrm{~cm})$ and the deeper soil fraction $(10-30 \mathrm{~cm}$, not shown). The top soil concentration of inorganic $\mathrm{N}$ increased slightly after cutting of the grass (Fig. 5). Application of $100 \mathrm{~kg} \mathrm{Nha}^{-1}$ caused a dramatic increase in both $\mathrm{NH}_{4}^{+}$and $\mathrm{NO}_{3}^{-}$(Fig. 5), while soil inorganic $\mathrm{N}$ increased less in the $200 \mathrm{~N}$ treatment. This difference may reflect the fact that the $\mathrm{N}$ fertiliser in the $200 \mathrm{~N}$ plot was applied by hand a few hours later and under drier conditions compared to that in the $100 \mathrm{~N}$ treatment of the main field where rainfall followed within a couple of hours after the application.

\subsection{Correlation analysis}

The $\mathrm{NH}_{4}^{+}$concentrations in apoplastic solution, leaf tissue and litter were mutually positively correlated (Table 2 ). The
$\mathrm{NH}_{3}$ compensation point derived from the apoplastic measurements was also positively correlated with leaf tissue $\mathrm{NH}_{4}^{+}$, but not with total leaf $\mathrm{N}$ content. Apoplastic $\mathrm{pH}$ and the $\mathrm{NH}_{4}^{+}$concentration in guttation droplets were not significantly correlated with any of the other parameters (Table 2).

\section{Discussion}

Before cutting, the tall grass had low $\mathrm{NH}_{4}^{+}$concentrations in both leaf apoplast and bulk tissue (Fig. 1a, 2a). This resulted in $\mathrm{NH}_{3}$ compensation points so low that the grass was not likely to emit $\mathrm{NH}_{3}$ before cutting which is in agreement with atmospheric $\mathrm{NH}_{3}$ concentration gradients above the canopy showing predominantly deposition fluxes (Milford et al., 2008). Extremely low tissue $\mathrm{NO}_{3}^{-}$concentrations (Fig. 2b) as well as low soil $\mathrm{NH}_{4}^{+}$and $\mathrm{NO}_{3}^{-}$levels (Fig. 5) also indicated that the small amounts of inorganic $\mathrm{N}$ available to the plants were efficiently taken up and utilised for growth and seed development at this stage. Before fertilisation, the soil content of $\mathrm{NH}_{4}^{+}$was 4 times higher than that of $\mathrm{NO}_{3}^{-}$(Fig. 5), which is not unusual for grassland soil (Whitehead, 1995).

Between cutting and fertilisation there was a re-growth period of one week in which the grass leaves first showed increased $\mathrm{NO}_{3}^{-}$concentrations (Fig. 2b) and 5 days later also increased $\mathrm{NH}_{4}^{+}$concentrations (Fig. 2a). Ryegrass has been shown to rapidly accumulate $\mathrm{NO}_{3}^{-}$in both leaves and stubble after cutting as $\mathrm{NO}_{3}^{-}$is involved in the osmotic adjustment (Ourry et al., 1989). Also the soluble $\mathrm{N}$ and total $\mathrm{N}$ concentrations of the leaves showed higher values during re-growth after cutting compared to the tall grass (Fig. 3a, b). The increase in these $\mathrm{N}$ pools was paralleled by slightly increasing $\mathrm{NO}_{3}^{-}$and $\mathrm{NH}_{4}^{+}$concentrations in the soil. Several authors have reported that during the first days after cutting, uptake of $\mathrm{N}$ is inhibited (Bakken et al., 1998; Ourry et al., 1988). In such case plants respond by allocating $\mathrm{N}$ from reserves in root and stubble to the developing leaves. This inhibition of uptake could explain the increasing levels of soil $\mathrm{NO}_{3}^{-}$and $\mathrm{NH}_{4}^{+}$after cutting. In Lolium perenne and Bromus erectus grown in nutrient solution, tissue $\mathrm{NH}_{4}^{+}$concentrations of expanding leaves did not start to increase until 6 days after cutting (Sutton et al., 2001). In the same experiment, apoplastic $\mathrm{NH}_{4}^{+}$concentrations increased in the new expanding leaves 3-6 days after cutting. Also in the present study, apoplastic $\mathrm{NH}_{4}^{+}$concentrations showed slightly higher values in expanding leaves during re-growth compared to the leaves of the tall grass (Fig. 1a). Increasing tissue concentrations of $\mathrm{NH}_{4}^{+}$and $\mathrm{NO}_{3}^{-}$can also result from shortening of the leaf growth zone and smaller dilution of the $\mathrm{N}$ transported to this zone after defoliation compared to the fully expanded leaves before cutting (Schäufele and Schnyder, 2001). 
Grass cutting has in several cases been reported to lead to $\mathrm{NH}_{3}$ volatilization from grassland (Milford et al., 1999, 2002; Loubet et al., 2001). The emitted $\mathrm{NH}_{3}$ may originate from the plants as a consequence of increased $\mathrm{N}$ pools during the period of leaf expansion. However, the potential for $\mathrm{NH}_{3}$ emission did not seem to increase after cutting in the present work since $\Gamma_{\text {apoplast }}$ (the ratio between apoplastic $\mathrm{NH}_{4}^{+}$and $\mathrm{H}^{+}$) were unaltered due to counteracting effects of decreased $\mathrm{pH}$ and increased $\mathrm{NH}_{4}^{+}$concentrations (Fig. 1c). Another source of $\mathrm{NH}_{3}$ emission could be the litter, i.e. senescent leaves attached to the stems or lying on the ground surface. Ammonium concentrations were considerably higher in the litter material compared to green leaves (Fig. 4) due to the protein degradation processes going on in the litter (Mattsson and Schjoerring, 2003). Senescence-related processes were probably also enhanced after cutting when both the climatic conditions and the proportion of litter out of total biomass were changed at the bottom of the canopy (David et al., 2008). In a tall canopy, $\mathrm{NH}_{3}$ emitted from the litter can be taken up by leaves positioned higher above the ground (Husted et al., 2000b; Nemitz et al., 2000) while in the absence of a tall canopy, the litter $\mathrm{NH}_{3}$ may escape to the atmosphere. High $\mathrm{NH}_{4}^{+}$concentrations and relatively high $\mathrm{pH}$ values in the litter also resulted in an extremely high $\Gamma_{\text {litter value }}$ (Table 1) indicating a strong potential for $\mathrm{NH}_{3}$ emission. In a non-fertilized grassland in the Netherlands, Wichink Kruit et al. (2007) observed an average canopy value of 2200, which is in line with that recorded for stems and young leaves in the present work (Table 1).

After fertilisation, all plant $\mathrm{N}$ pools increased with peak values already on the first day after fertilisation. Micrometeorological measurements also showed high $\mathrm{NH}_{3}$ emissions after fertilisation with some contribution from the fertiliser itself during the first 2 days (Milford et al., 2008). The fertiliser was rapidly dissolved in the soil solution since it was raining the same afternoon as the main field was fertilised (Sutton et al., 2008). Consequently, the fertiliser contamination was restricted to a very short period. The fertilisation was also reflected in higher $\mathrm{NH}_{4}^{+}$concentrations in guttation droplets collected at the leaf tips in the early mornings after fertilisation (not shown).

Ammonium concentrations in both leaf tissue and apoplast started to decrease again already a few days after fertilisation (Fig. 1a, 2a) while leaf tissue $\mathrm{NO}_{3}^{-}$concentrations remained high for the rest of the experiment (Fig. 2b). This may partly reflect declining soil $\mathrm{NH}_{4}^{+}$levels (Fig. 5) and partly rapid assimilation of $\mathrm{NH}_{4}^{+}$in the plant cells, while $\mathrm{NO}_{3}^{-}$was stored in the leaf cell vacuoles for later use. It has previously been shown that when $\mathrm{NH}_{4} \mathrm{NO}_{3}$ is supplied to plant roots, $\mathrm{NH}_{4}^{+}$ is absorbed more readily than $\mathrm{NO}_{3}^{-}$(Bloom, 1981; Clarkson et al., 1986). Nitrate accumulates in grass herbage when the rate of uptake by the roots exceeds the rate of conversion to organic N (Whitehead, 1995). The $\mathrm{NH}_{4}^{+}$concentrations in apoplast and bulk tissue were obviously sensitive parameters responding rapidly to fluctuations in soil nitrogen availability. Also in a laboratory experiment with Lolium perenne and Bromus erectus both leaf tissue and apoplastic $\mathrm{NH}_{4}^{+}$concentrations were shown to respond rapidly to changing $\mathrm{NH}_{4}^{+}$ concentrations in the nutrient solution (Mattsson and Schjoerring, 2002).

A correlation analysis revealed that the stomatal $\mathrm{NH}_{3} \mathrm{com}-$ pensation point calculated on the basis of apoplastic parameters was positively correlated with the bulk tissue $\mathrm{NH}_{4}^{+}$concentration in leaves and litter (Table 2). Some previous investigations have likewise shown good correlation between apoplastic and leaf tissue $\mathrm{NH}_{4}^{+}$concentrations (Mattsson et al., 1998; Mattsson and Schjoerring, 2002), suggesting that the tissue $\mathrm{NH}_{4}^{+}$concentration may be used as an indicator of the $\mathrm{NH}_{3}$ compensation point. Other studies have found the correlation to depend on growth conditions (Herrmann et al., 2008) or not to be present (Hill et al., 2002).

\section{Conclusions}

We conclude that the management practice has a major impact on the potential plant-atmosphere $\mathrm{NH}_{3}$ exchange in grassland by influencing both plant and soil $\mathrm{N}$ parameters. The $\mathrm{NH}_{3}$ compensation point derived from apoplastic measurements was positively correlated with bulk tissue $\mathrm{NH}_{4}^{+}$ concentrations in leaves and litter. This suggests that measurements of $\mathrm{NH}_{4}^{+}$and $\mathrm{pH}$ in bulk extracts of plant material in grassland can be used as a simple indicator of the $\mathrm{NH}_{3}$ exchange potential.

Acknowledgements. The authors gratefully acknowledge the support of many different funders and colleagues to this work. The measurements were conducted under the frame of the GRAMINAE project funded by the European Commission (ENV4-CT98-0722). Final synthesis of this paper was conducted as part of the NitroEurope Integrated Project.

Edited by: K. Pilegaard

\section{References}

Bakken, A. K., Macduff, J. H., and Collison, M.: Dynamics of nitrogen remobilization in defoliated Phleum pratense and Festuca pratensis under short and long photoperiods, Physiol. Plant., 103, 426-436, 1998.

Bloom, A. J. and Chapin, F. S.: Differences in steady-state net ammonium and nitrate influx by cold- and warm adapted barley varieties, Plant Physiol., 68, 1064-1067, 1981.

Clarkson, D. T., Hopper, M. J., and Jones, L. H. P.: The effect of root temperature on the uptake of nitrogen and the relative size of the root system in Lolium perenne. I. Solutions containing both $\mathrm{NH}_{4}^{+}$and $\mathrm{NO}_{3}^{-}$, Plant Cell Environ., 9, 535-545, 1986.

David, M., Roche, R., Mattsson M., Schjoerring, J. K., Sutton, M. A., Daemmgen, U., and Cellier, P.: Analysis of ammonia fluxes with intensively managed grassland using dynamic chambers II. 
The effect of management options, Biogeosciences Discuss., (in press), 2009.

Farquhar, G. D., Firth, P. M., Wetselaar, R., and Weir, B.: On the gaseous exchange of ammonia between leaves and the environment. Determination of the ammonia compensation point, Plant Physiol., 66, 710-714, 1980.

Hanstein, S., Mattsson, M., Jaeger, H.-J., and Schjoerring, J. K.: Uptake and utilization of atmospheric ammonia in three native Poaceae species: Leaf conductances, composition of apoplastic solution and interactions with nitrogen supply, New Phytol., 141, 71-83, 1999.

Herrmann, B., Jones, S. K., Fuhrer, J., Feller, U., and Neftel, A.: N budget and $\mathrm{NH}_{3}$ exchange of a grass/clover crop at two levels of $\mathrm{N}$ application, Plant and Soil, 235, 243-252, 2001.

Herrmann, B., Mattsson, M., Jones, S. K., Cellier, P., Milford, C., Sutton, M. A., Schjoerring, J. K., and Neftel, A.: Vertical structure and diurnal variability of ammonia exchange potential within an intensively managed grass canopy, Biogeosciences, 6 , 15-23, 2009, http://www.biogeosciences.net/6/15/2009/.

Hill, P. W., Raven, J. A., and Sutton, M. A.: Leaf age-related differences in apoplastic $\mathrm{NH}_{4}^{+}$concentration, $\mathrm{pH}$ and the $\mathrm{NH}_{3}$ compensation point for a wild perennial, J. Exp. Bot., 53, 277-286, 2002.

Horvath, L., Astalos, M., Fuhrer, E., Meszaros, R., and Weidinger, T.: Measurement of ammonia exchange over grassland in the Hungarian Great Plain, Agric. Forest Meteorol., 130, 282-298, 2005

Husted, S. and Schjoerring, J. K.: Apoplastic pH and ammonium concentration in leaves of Brassica napus L., Plant Physiol., 109, 1453-1460, 1995.

Husted, S. and Schjoerring, J. K.: Ammonia flux between oilseed rape plants and the atmosphere in response to changes in leaf temperature, light intensity, and air humidity, Plant Physiol., 112, 67-74, 1996.

Husted, S., Mattsson, M, and Schjoerring, J. K.: Ammonia compensation points in two cultivars of Hordeum vulgare L. during vegetative and generative growth, Plant, Cell Environ., 19, 12991306, 1996.

Husted, S., Hebbern, C. A., Mattsson, M., and Schjoerring, J. K.: Determination of ammonium, low molecular weight amines and amides in plant tissue, Physiol. Plant., 109, 167-179, 2000a.

Husted, S., Schjoerring, J. K., Nielsen, K. H. Nemitz, E., and Sutton, M. A.: Stomatal compensation points for ammonia in oilseed rape plants under field conditions, Agr. Forest Meteorol., 105, 371-383, 2000b.

Loubet, B., Milford, C., Hill, P. W., Tang, Y. S., Cellier, P., and Sutton, M. S.: Seasonal variability of apoplastic $\mathrm{NH}_{4}^{+}$and $\mathrm{pH}$ in an intensively managed grassland, Plant and Soil, 238, 97-110, 2002 .

Mattsson, M. and Schjoerring, J. K.: Ammonia emission from young barley plant: influence of $\mathrm{N}$-source, light/dark cycles and inhibition of glutamine synthetase, J. Exp. Bot., 47, 477-484, 1996.

Mattsson, M., Häusler, R. E., Leegood, R. C., Lea, P. J., and Schjoerring, J. K.: Leaf-atmosphere ammonia exchange in barley mutants with reduced activities of glutamine synthetase, Plant Physiol., 114, 1307-1312, 1997.

Mattsson, M., Husted, S., and Schjoerring, J. K.: Influence of nitrogen nutrition and metabolism on ammonia volatilization in plants, Nutr. Cycl. Agroecosys., 51, 35-40, 1998.

Mattsson, M. and Schjoerring, J. K.: Dynamic and steady state responses of inorganic nitrogen pools and $\mathrm{NH}_{3}$ exchange in leaves of Lolium perenne and Bromus erectus to changes in root supply, Plant Physiol, 128, 742-750, 2002.

Mattsson, M. and Schjoerring, J. K.: Senescence-induced changes in apoplastic and bulk tissue ammonia concentrations of ryegrass leaves, New Phytol., 160, 489-499, 2003.

Mattsson, M., Herrmann, B., Jones, S., Borella, S., Dorsey, J., and Schjoerring, J. K.: Contribution of different grass species to $\mathrm{NH}_{3}$ exchange between plants and the atmosphere in intensively managed grassland, Biogeosciences, 6, 59-66, 2009, http://www.biogeosciences.net/6/59/2009/.

Milford, C., Theobald, M. R., Nemitz, E. N., Hargreaves, K. J., Horvath, L., Raso, J., Daemmgen, U., Neftel, A., Jones, S., Hensen, A., Loubet, B., and Sutton, M. A.: Ammonia fluxes in relation to cutting and fertilization of intensively managed grassland derived from an inter-comparison of gradient measurements, Biogeosciences Discuss., 5, 4699-4744, 2008, http://www.biogeosciences-discuss.net/5/4699/2008/.

Nemitz, E., Sutton, M. A., Gut, A., San José, R., Husted, S., and Schjoerring, J. K.: Sources and sinks of ammonia within an oilseed rape canopy, Agric. Forest Meteorol., 105, 385-404, 2000.

Ourry, A., Boucard, J., and Salette, J.: Nitrogen remobilisation from stubble and roots during re-growth of defoliated ryegrass, J. Exp. Bot., 39, 803-809, 1988

Ourry, A., Gonzales, B., and Boucaud, J.: Osmoregulation and role of nitrate during regrowth after cutting of ryegrass (Lolium perenne), Physiol. Plant., 76, 177-182, 1989.

Riedo, M., Milford, C., Schmid, M., and Sutton, M. A.: Coupling soil-plant-atmosphere exchange of ammonia with ecosystem functioning in grasslands, Ecol. Model., 158, 83-110, 2002.

Schjoerring, J. K. and Mattsson, M.: Quantification of ammonia exchange between agricultural cropland and the atmosphere: Measurements over two complete growth cycles of oilseed rape, wheat, barley and pea, Plant Soil, 228, 105-115, 2001.

Sutton, M. A., Milford, C., Nemitz, E., Theobald, M. R., Hill, P W., Fowler, D., Schjoerring, J. K., Mattsson, M., Nielsen, K. H., Husted, S., Erisman, J. W., Otjes, R., Hensen, A., Cellier, P., Loubet, B., David, M., Genermont, S., Neftel, A., Blatter, A., Hermann, B., Jones, S. K., Horvath, L., Führer, E., Mantzanas, C., Koukoura, K., Gallagher, M., Williams, P., and Riedo, M.: Biosphere-atmosphere interactions of ammonia with grasslands: experimental strategy and results from a new European initiative, Plant Soil, 228, 131-135, 2001.

Schäufele, R. and Schnyder, H.: Carbon and nitrogen deposition in expanding tissue elements of perennial ryegrass (Lolium perenne L) leaves during non-steady growth after defoliation, Plant. Cell Environ., 24, 407-417, 2001.

Sommer, S. G., Schjoerring, J. K., and Denmead, O. T.: Ammonia emission from mineral fertilizers and fertilized crops, Adv. Agron., 82, 557-622, 2004.

Sutton, M. A., Nemitz, E., Theobald, M. R., Milford, C., Dorsey, J. R., Gallagher, M. W., Hensen, A., Jongejan, P. A. C., Erisman, J.,W., Mattsson, M., Schjoerring, J. K., Cellier, P., Loubet, B., Roche, R., Neftel, A., Herrmann, B., Jones, S., Lehman, B. E., Horvath, L., Weidinger, T., Rajkai, K., Burkhardt, J., Löpmeier, F. J., and Daemmgen U.: Dynamics of ammonia exchange with 
cut grassland: Strategy and implementation of the GRAMINAE Integrated Experiment, Biogeosciences Discuss., 5, 3347-3407, 2008, http://www.biogeosciences-discuss.net/5/3347/2008/.

Trebs, I., Lara, L. L., Zeri, L. M. M., Gatti, L. V., Artaxo, P., Dlugi, R., Slanina, J., Andreae, M. O., and Meixner, F. X.: Dry and wet deposition of inorganic nitrogen compounds to a tropical pasture site (Rondonia, Brazil), Atmos. Chem. Phys., 6, 447-469, 2006, http://www.atmos-chem-phys.net/6/447/2006/.

van Hove, L. W. A., Heeres, P., and Bossen, M. E.: The annual variation in stomatal ammonia compensation point of rye grass (Lolium perenne L.) leaves in an intensively managed grassland, Atmos. Environ., 36, 2965-2977, 2002.
Whitehead, D. C.: Grasses: Uptake of nitrogen and effects on morphology and physiology. In: DC Whitehead, Ed. Grassland nitrogen. CAB International, UK 16-34, 1995.

Wichink Kruit, R. J., van Pul, W. A. J., Otjes, R. P., Hofschreuder, P., Jacobs, A. F. G., and Holtslag, A. A. M.: Ammonia fluxes and derived canopy compensation points over non-fertilized agricultural grassland in The Netherlands using the new gradient ammonia - high accuracy - monitor (GRAHAM), Atmos. Environ., 41, 1275-1287, 2007. 